\title{
Nibrin expression in oral squamous cell carcinoma: association with clinicopathological parameters
}

\author{
Jigna H. Dave, Hemangini H. Vora, Trupti I. Trivedi, Nandita R. Ghosh \\ Division of Molecular Endocrinology, Department of Cancer Biology, the Gujarat Cancer and Research Institute, Asarwa, Ahmedabad 380016, India. \\ Correspondence to: Dr. Nandita R. Ghosh, Division of Molecular Endocrinology, Department of Cancer Biology, the Gujarat Cancer and Research \\ Institute, Asarwa, Ahmedabad 380016, India. E-mail: nandita.ghosh@gcriindia.org
}

How to cite this article: Dave JH, Vora HH, Trivedi TI, Ghosh NR. Nibrin expression in oral squamous cell carcinoma: association with clinicopathological parameters. J Cancer Metastasis Treat 2016;2:436-42.

Article history:

Received: 02-11-2015

Accepted: 08-11-2016

Published: 25-11-2016

Key words:

Nibrin protein expression, oral squamous cell carcinoma, clinicopathological parameters

\begin{abstract}
Aim: The present study sought to discover the role of Nibrin protein in 100 patients with oral squamous cell carcinoma (OSCC) and its potential relationship with clinicopathological parameters. Methods: Nibrin expression was evaluated immunohistochemically using the modified H-score method. Results: The present study included $20 \%$ of patients with stage I disease, $22 \%$ of patients with stage II disease, $18 \%$ of patients with stage III disease, and $40 \%$ of patients with stage IV disease. Nibrin showed a significant positive correlation with moderately/poorly differentiated tumor tissues $(P=0.028)$, while significant inverse correlation of Nibrin expression was observed with tumor size $(P=0.018)$ and tumor stage $(P=0.039)$. Further, using univariate survival analysis it was observed that strong Nibrin expression was significantly associated with disease relapse in early stage OSCC patients $(P=0.049)$. Conclusion: Thus, the present study revealed that Nibrin could be used as a prognostic marker in patients with early stage OSCC.
\end{abstract}

\section{INTRODUCTION}

Carcinomas of the oral cavity, including cancer originating from the buccal mucosa and tongue are of 10 most common cancers in the world with an increasing trend of incidence. ${ }^{[1,2]}$ Squamous cell carcinoma (SCC) is the most common type of oral cancer which accounts for more than $90 \%$ of oral malignancies which is characterized by an aggressive growth pattern, high-degree of local invasiveness, and cervical lymph node spread. ${ }^{[1,3]}$ In India, oral squamous cell carcinoma (OSCC) is the leading cause of death which stands for $35-40 \%$ of all malignancies which is owed to the increased prevalence of lifestyle habits like chewing areca-nut/betel nut quid/tobacco and smoking with heavy alcohol consumption serving as a potent cofactor ${ }^{[4-6]}$ The survival of patients with oral cancer has remained unchanged even with the improved therapeutic modalities, over the last 3 decades. ${ }^{[4]}$ The resultant poor prognosis is owed to a late stage diagnosis, low response rate to current therapeutic strategies, high risk of primary site recurrence and

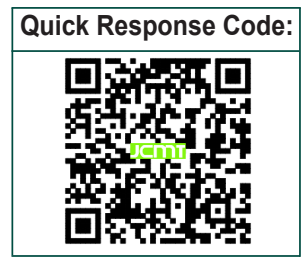


aggressive metastases to loco-regional lymph nodes, strongly suggestive of an urge to improve the treatment efficacy and diagnostic capabilities. Over the last decade, scientific research related to the specific pathways which are relevant to the development and progression of this disease has been performed to investigate biological, diagnostic and prognostic parameters. ${ }^{[7-10]}$

DNA damage is one of the underlying causes for mutations which is very numerous and appears to be a fundamental problem for life leading to cancer. In human cells, the estimated average number of DNA damages occurring per hour is about 800 which reach to 19,200 per day. ${ }^{[11]}$ If, such DNA damages are not repaired in dividing cells, cause errors during DNA synthesis leading to mutations which can give rise to cancer. Thus individuals are often at increased risk of cancer with an inherited damage in DNA repair capability. ${ }^{[12]}$

Nijmegen breakage syndrome (NBS) is a chromosomalinstability syndrome associated with cancer predisposition, growth retardation, microcephaly, radiosensitivity and immunodeficiency. ${ }^{[13-15]}$ The NBS1/ Nibrin/p95 is a member of the DNA double-strand break (DSB) repair complex (hMre11 complex) which is a product of the defective gene in NBS (the NBS gene) located on human chromosome $8 q 21$.14-16] $^{\text {The }}$ Nibrin containing protein complex [Mre11-Rad50Nbs1(MRN) complex] binds to the edges of the DNA double stranded break and remains attached to this site until the break gets repaired. ${ }^{[17]}$ Nibrin is also involved in various signaling cascades other than DSBs induced by irradiation such as mitotic $V(D) J$ rearrangements in $T$ and $B$ lymphocytes, maintenance of telomere function and meiotic recombination. ${ }^{[18,19]}$ Once ataxia-telangiectasia mutated protein phosphorylates NBS1, it then carries out its checkpoint

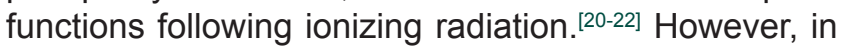
certain types of human cancer rare or no mutations of NBS1 have been studied. ${ }^{[23-25]}$ In addition, during the process of carcinogenesis NBS1 is expressed in highly proliferating tissues. ${ }^{[26]}$ On the basis of this information, the aim of this study was to assess whether the Nibrin expression would relate to clinicopathological variables and if it could predict survival or recurrence in OSCC.

\section{METHODS}

\section{Study population}

A total of 100 untreated patients with histolpathologically confirmed OSCC of tongue and buccal mucosa evaluated between 2011 and 2013 at our institute were included in this study. Formalin fixed and paraffin embedded primary tumor tissue blocks (buccal mucosa: $n=39$, tongue: $n=61$ ) and histologically confirmed adjacent normal tissue blocks were collected from the histopathology department of our institute. The detail clinical history of the patients [age, gender, tobacco habit, site of disease, tumor-node-metastasis (TNM) stage, histopathological findings, treatment given, etc.] was obtained from the case files maintained at our institute. In patients with OSCC the disease was staged according to the criteria of the American Joint Committee on Cancer pTNM classification. Thus, the present study included 20 patients with stage I disease, 22 patients with stage II disease, 18 patients with stage III disease and 40 patients with stage IV disease. This study was approved by our institutional review committee for dissertation/thesis/publications/ conference presentations and institutional ethics committee.

\section{Immunohistochemistry}

Immunohistochemistry of Nibrin was performed using the avidine-biotin complex technique in which formalin fixed paraffin embedded tissue sections (4 $\mu \mathrm{m})$ were mounted on 3-aminopropyletriethoxy silane coated glass slides. The sections were first deparafinized using xylene and then rehydrated using graded alcohol. Endogenous peroxidase activity was blocked using $3 \%$ hydrogen peroxide prepared in methanol for $15 \mathrm{~min}$. Antigenicity of the processed tissue sections was retrieved by cooking the sections in $10 \mathrm{mmol} / \mathrm{L}$ tri-sodium citrate buffer $(\mathrm{pH} 6.0)$ solution with $0.05 \%$ tween-20 for 20 min in a pressure cooker. Sections were then allowed to cool at room temperature. For Nibrin immunostainings, a commercial mouse monoclonal antibody (clone 1D7, Santa Cruz Biotechnology, Santa Cruz, USA) at dilution of 1:100 prepared in tris buffered saline was applied to the sections and were then incubated overnight at $4{ }^{\circ} \mathrm{C}$. For immunohistochemical detection of the antibody reaction, we used Novolink polymer detection kit from Novocastra. Sections were then dehydrated, cleared in xylene and mounted in dibutylphthalate xylene. As positive controls, formalinfixed paraffin-embedded tissue sections with intense staining for a given marker were included with each staining procedure.

\section{Assessment of Nibrin expression}

All sections were scored independently by two independent researchers in a blinded fashion. The staining intensities and the percentage of positive cells were separately assessed in primary tumor tissues $(n=100)$ and their corresponding adjacent normal squamous epithelium $(n=100)$. As the Nibrin expression was not uniform in different parts of the epithelium or cancerous tissue, we used modified 
histoscore ( $\mathrm{H}$-score) method to combine the staining intensity and percentage of Nibrin expressing cells. More specifically, the staining intensity was assessed with a four-point scale from negative (0); weak (1); moderate (2); and strong intensity (3). The extent of the staining was expressed as percentage of positive cells $(0-100 \%)$ by $10 \%$ intervals. The Nibrin histoscore was counted by multiplying the intensity level by percentage of positive cells resulting in a value between 0 and 300 . Data were divided into groups by histoscore levels. Accordingly the cancer and their corresponding adjacent normal specimens were grouped by Nibrin expression score based on the median score value of cancerous and adjacent normal tissues respectively into "weak expression" (Tumor: scores 0-209 and Normal: scores 0-144) and "strong expression" (Tumor: scores 210-300 and Normal: scores 145-300).

\section{Follow-up and disease status of OSCC patients}

Out of total 100 OSCC patients, for overall survival analysis, only 90 patients could be followed for a period of 24 months or until death within that period. On the other hand, for relapse-free survival study, 78 of 100 patients with or without recurrence within that period were considered. The remaining 12 patients could not be included for relapse-free survival study due to presence of persistent disease.

\section{Statistical analysis}

The data were analyzed statistically using SPSS software version 17.0 (Chicago, IL, USA). The two tailed chi-square test was used to assess associations between two parameters. Correlations between two parameters were calculated using spearman's correlation coefficient $(r)$. To compare the Nibrin expression in cancerous and adjacent normal tissues, paired sample $t$-test was used. Univariate survival analysis was performed using Kaplan-Meier survival function and differences in survival were tested for statistical significance using the log-rank statistics. $P$ values $\leq 0.05$ were considered significant.

\section{RESULTS}

\section{Nibrin expression in OSCC}

Of the tongue and buccal mucosa cancer tissue, Nibrin protein expression was evaluated with nuclear location of the immunoreactions, Nibrin was expressed in $99 \%$ of tumors and $92 \%$ of the adjacent normal squamous epithelium [Figure 1]. $\mathrm{H}$-score varied from 0 to 300 in both OSCC and adjacent normal tissues. Median $\mathrm{H}$-score for tumor tissues was 210 while that for the adjacent normal tissue was 145 . The tissues expressing Nibrin below the median $\mathrm{H}$-score was consider as a weak expression and tissue expressing Nibrin above the median $\mathrm{H}$-score was considered as a strong expression.

\section{Relation of Nibrin expression with clinical and histopathological parameters}

Two tailed chi-square test and spearman's correlation coefficient $(r)$ were used to assess correlation between the Nibrin protein expression and clinicopathological parameters in tumor tissues. The relations of Nibrin immunoreactivity with clinical and histopathological parameters are depicted in Table 1 , respectively. In tumor tissues an inverse correlation of Nibrin expression was found with tumor size $\left(\chi^{2}=5.622, r=-0.237, P=\right.$ $0.018)$ and tumor stage $\left(\chi^{2}=6.600, r=-0.194, P=\right.$ 0.039 ) while, significant positive correlation was found with strong Nibrin expression and moderately/poorly differentiated tumor tissues $\left(\chi^{2}=4.857, r=+0.220\right.$, $P=0.028$ ). No significant association was detected with Nibrin expression and other clinicopathological parameters.

\section{Univariate survival analysis}

According to Kaplan-Meier survival analysis similar incidence of death observed in total patients with strong $(42 \%, 20 / 48$, log-rank $=0.112, \mathrm{df}=1, P=0.737)$

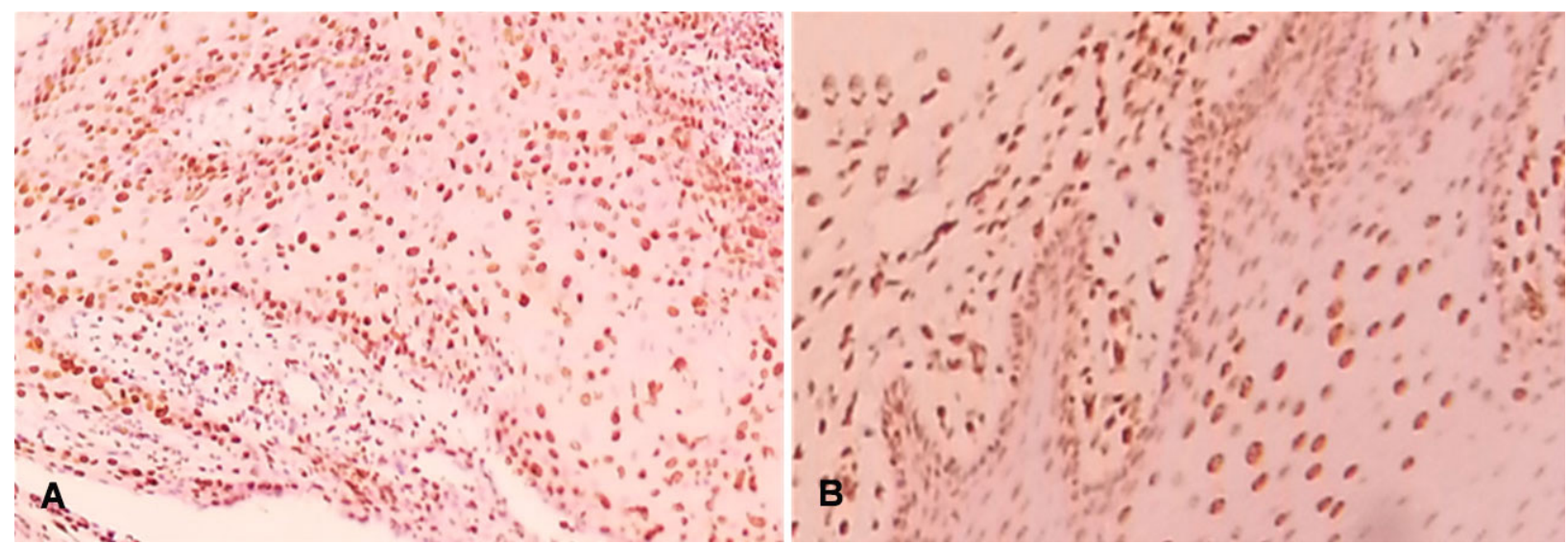

Figure 1: Nibrin protein expression $(\mathrm{IHC}, \times 10)$. (A) Nuclear protein expression of Nibrin in primary tumor of OSCC; (B) nuclear protein expression of Nibrin in adjacent normal tissue of primary OSCC tumor tissue. OSCC: oral squamous cell carcinoma 
Table 1: Relation of Nibrin immunoreactivity with clinical and pathological parameters in OSCC tissue

\begin{tabular}{|c|c|c|c|c|c|}
\hline \multicolumn{6}{|c|}{ Nibrin expression in tumor (Median: 210) } \\
\hline Variables & $\boldsymbol{n}$ & Weak, $n(\%)$ & Strong, $n(\%)$ & Correlation $(r)$ & $\boldsymbol{P}$ \\
\hline \multicolumn{6}{|l|}{ Age (year): median 45} \\
\hline $\begin{array}{l}<45 \\
\geq 45\end{array}$ & $\begin{array}{l}47 \\
53\end{array}$ & $\begin{array}{l}22(47) \\
25(47)\end{array}$ & $\begin{array}{l}25(53) \\
28(53)\end{array}$ & -0.004 & 0.972 \\
\hline \multicolumn{6}{|l|}{ Gender } \\
\hline Male & 75 & $33(44)$ & $42(56)$ & +0.104 & 0.303 \\
\hline Female & 25 & $14(56)$ & $11(44)$ & & \\
\hline \multicolumn{6}{|l|}{ Anatomic site } \\
\hline Tongue & 61 & $30(49)$ & $31(51)$ & +0.055 & 0.589 \\
\hline Buccal mucosa & 39 & $17(44)$ & $22(56)$ & & \\
\hline \multicolumn{6}{|l|}{ Tobacco habit } \\
\hline Present & 86 & $38(44)$ & $48(56)$ & +0.140 & 0.100 \\
\hline \multicolumn{6}{|l|}{ Disease status $(n=78)$} \\
\hline No recurrence & 46 & $23(50)$ & $23(50)$ & +0.031 & 0.789 \\
\hline $\begin{array}{l}\text { Recurrence } \\
\text { Rece }\end{array}$ & 32 & $15(47)$ & & & \\
\hline \multicolumn{6}{|l|}{ Disease outcome $(n=90)$} \\
\hline Alive & 51 & $23(45)$ & $28(55)$ & -0.036 & 0.737 \\
\hline Dead & 39 & $19(49)$ & $20(51)$ & & \\
\hline \multicolumn{6}{|l|}{ Tumor size } \\
\hline $\mathrm{T} 1-\mathrm{T} 2$ & 71 & $28(39)$ & $43(61)$ & -0.237 & 0.018 \\
\hline \multirow{2}{*}{\multicolumn{5}{|c|}{ Tumor stage }} & \\
\hline I & & & $12(60)$ & -0.194 & 0.039 \\
\hline II & 22 & $8(36)$ & $14(64)$ & & \\
\hline III & 18 & $6(33)$ & $12(67)$ & & \\
\hline IV & 40 & $25(62)$ & $15(38)$ & & \\
\hline \multicolumn{6}{|l|}{ Nodal status } \\
\hline Negative & 59 & $25(42)$ & $34(58)$ & -0.111 & 0.271 \\
\hline \multirow{2}{*}{\multicolumn{6}{|c|}{ Tumor differentiation }} \\
\hline & & & & & \\
\hline Well & 50 & $29(58)$ & $21(42)$ & +0.220 & 0.028 \\
\hline \multicolumn{6}{|l|}{ Keratin } \\
\hline Absent & 79 & $34(43)$ & $45(57)$ & -0.154 & 0.126 \\
\hline Present & 21 & $13(62)$ & $8(38)$ & & \\
\hline \multicolumn{6}{|l|}{ Lymphatic permeation } \\
\hline Absent & 91 & $43(47)$ & $48(53)$ & +0.095 & 0.874 \\
\hline \multirow{2}{*}{\multicolumn{6}{|c|}{ Vascular permeation }} \\
\hline & & & & & \\
\hline Absent & 99 & $47(47)$ & $52(53)$ & +0.095 & 0.349 \\
\hline $\begin{array}{l}\text { Present } \\
\text { Perineural inyasion }\end{array}$ & 1 & $0(0)$ & $1(100)$ & & \\
\hline \multicolumn{6}{|l|}{ Perineural invasion } \\
\hline Present & 18 & $7(39)$ & $11(61)$ & +0.010 & 0.451 \\
\hline \multicolumn{6}{|l|}{ Lymphocytic stromal response } \\
\hline Ábsent & 46 & $21(46)$ & $25(54)$ & -0.025 & 0.806 \\
\hline Present & 54 & $26(48)$ & $28(52)$ & & \\
\hline
\end{tabular}

OSCC: oral squamous cell carcinoma

and weak Nibrin expression (45\%, 19/42). In relation to relapse free survival also we were unable to find any significant incidence of disease relapse in patients with strong $(42 \%, 17 / 40$, log-rank $=0.006, \mathrm{df}=1, P=0.937)$ and weak Nibrin expression $(39 \%, 15 / 38)$. Although we were unable to obtain any significant findings in total patients, we further sub grouped patients into early and advanced stage disease and surprisingly, we observed that in patients with early stage disease, a significant high incidence of disease relapse was observed in patients with strong Nibrin expression $(43 \%, 10 / 23$, log-rank $=3.884$, df $=1, P=0.049)$ as compared to patients with weak Nibrin expression $(8 \%, 1 / 12)$ [Table 2 and Figure 2]. No such significant difference was noted for overall survival in this subgroup of patients. On the other hand in patients with advanced disease, Nibrin expression failed to discriminate such high and low risk sub group patients for survival.

\section{DISCUSSION}

Nibrin (p95, NBN, NBS1, NBS) is a 754-amino acid polypeptide which is involved in the recognition and the repair of DSBs. ${ }^{[15,27-29]}$ It interacts with Mre11 and RAD50 to form the MRN complex and is required for translocation of this complex to sites of DSBs. ${ }^{[29]}$ Although, in advanced head and neck SCC the prognostic significance of over expression of Nibrin by immunohistochemistry has been identified. ${ }^{[30]}$ However, data on the correlation of Nibrin with the clinicopathological prognosticators are limited. So, the current study evaluated correlation between Nibrin expression with clinicopathological parameters in total 100 patients with SCC of tongue and buccal mucosa.

In the present study, we observed nuclear expression of Nibrin in OSCC tissues and its corresponding adjacent normal tissues. However, there was no significant 
Table 2: Univariate survival analysis (Kaplan-Meier survival function) of Nibrin expression

\begin{tabular}{|c|c|c|c|c|c|}
\hline Variable & $n$ & Patients relapsed or died, $n(\%)$ & Log-rank & df & $\boldsymbol{P}$ \\
\hline \multicolumn{6}{|c|}{ Relapse free survival } \\
\hline \multicolumn{6}{|c|}{ Nibrin (total patients, $n=78$ ) } \\
\hline Weak & 38 & $15(39)^{*}$ & 0.006 & 1 & 0.937 \\
\hline Strong & 40 & $17(42)^{*}$ & & & \\
\hline \multicolumn{6}{|c|}{ Nibrin (early stage patients, $n=35$ ) } \\
\hline Weak & 12 & $1(8)^{*}$ & 3.884 & 1 & 0.049 \\
\hline Strong & 23 & $10(43)^{*}$ & & & \\
\hline \multicolumn{6}{|c|}{ Nibrin (advanced stage patients, $n=43$ ) } \\
\hline Weak & 26 & $14(54)^{*}$ & 0.593 & 1 & 0.441 \\
\hline Strong & 17 & $7(41)^{*}$ & & & \\
\hline \multicolumn{6}{|c|}{ Overall survival } \\
\hline \multicolumn{6}{|c|}{ Nibrin (total patients, $n=90$ ) } \\
\hline Weak & 42 & 19 (45)\# & 0.112 & 1 & 0.737 \\
\hline Strong & 48 & 20 (42)\# & & & \\
\hline \multicolumn{6}{|c|}{ Nibrin (early stage patients, $n=38$ ) } \\
\hline Weak & 13 & $2(15) \#$ & 0.659 & 1 & 0.417 \\
\hline Strong & 25 & 7 (28)\# & & & \\
\hline \multicolumn{6}{|c|}{ Nibrin (advanced stage patients, $n=52$ ) } \\
\hline Weak & 29 & 17 (59)\# & 0.010 & 1 & 0.920 \\
\hline Strong & 23 & $13(56) \#$ & & & \\
\hline
\end{tabular}

*: patients relapsed; \#: patients died

difference in Nibrin expression between OSCC tissues and their corresponding adjacent normal tissues $(t=$ $-0.455, \mathrm{df}=99, P=0.657$ ). Along with that in OSCC tissues, Nibrin expression was significantly positively correlated with tumor differentiation and significantly inversely correlated with tumor size and tumor stage, suggesting that up-regulation of Nibrin may be an early event in OSCC development. In accordance with our results, Ali-Fehmi et al. ${ }^{[31]}$ also showed that NBS1 does not show markedly higher expression in all ovarian cancer patients compared to women with serous cyst adenoma and those with normal ovaries.

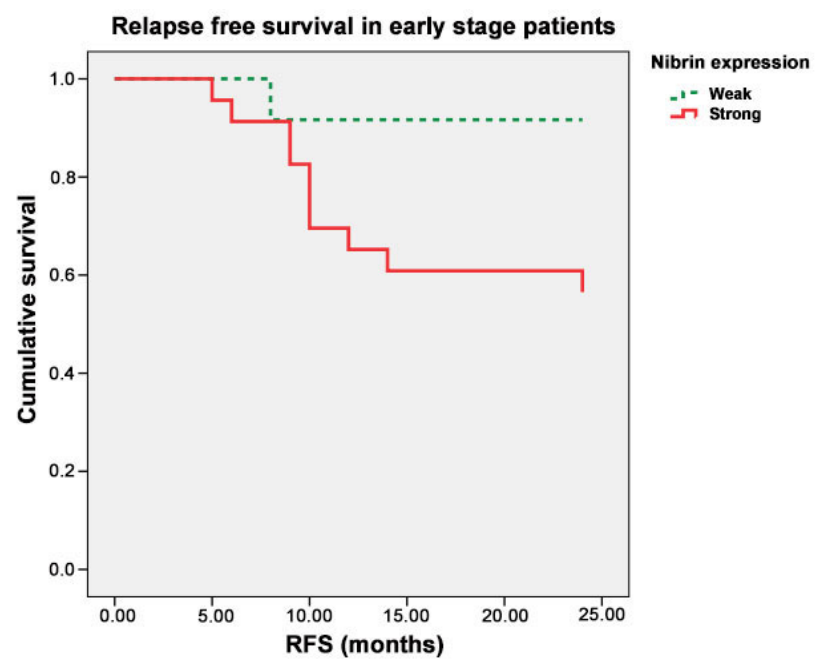

Figure 2: Kaplan-Meier univariate survival analysis of patients with early stage disease indicating significant high incidence of disease relapse in patients with strong Nibrin expression $(P=0.049)$. RFS: relapse-free survival
Plisiecka-Halasa et al. ${ }^{[25]}$ also showed that in human ovarian tumor tissues Nibrin expression was marked as strong nuclear staining which was present in both tumors and normal tissues. Further, Nibrin expression is up-regulated in adjacent normal tissues of OSCC tissue which is compatible with the hypothesis that Nibrin is a tumor suppressor gene. ${ }^{[32]}$ In contrast with our findings, Hsu et al. ${ }^{[30]}$ showed that Nibrin over expression was significantly correlated with high tumor size and metastatic dieses in OSCC patients which may be because of the inclusion of more number of patients with locally advanced diseases. Ehlers et al. ${ }^{[33]}$ also showed that Nibrin was associated with strong tumor severity and metastatic death marker in uveal melanoma. However, similar expression of NBS1 in class 1 tumors and normal uveal melanocytes suggests that up-regulation of NBS1 may be a late event in melanoma progression.

Kaplan-Meier univariate survival analysis showed that in patients with early stage disease high number of patients relapsed with strong Nibrin expression. However, our findings not only observed increased expression pattern of Nibrin in early stage patients but also found a strong correlation between increased Nibrin expressions in the onset of the disease with higher probability of recurrence. This could be attributed to the fact that since Nibrin acts as a sensor molecule of MRN complex which further activates the other DNA repair molecules, it might have a plausible role in constitutively activating these downstream molecules eventually leading to disease relapse in patients. While Hsu et al. ${ }^{[30]}$ found that in OSCC 
patients strong Nibrin expression was associated significantly with shorter overall survival compared with weak expression. Ehlers et al. ${ }^{[33]}$ have also found that in uveal melanoma, the 6-year survival was $100 \%$ for the low NBS1 group and $22 \%$ for the high NBS1 group $(P=0.01)$. In the breast carcinoma, patients with NBS1-aberrant tumors seemed to have poorer survival than the patients with NBS1 normal tumors. This indicates that the NBS1 deficiency predicts poor survival of the breast carcinoma patients. ${ }^{[34]}$

In conclusion, our study discovered that a Nibrin protein expression is significant in lower tumor size and early stage disease in OSCC indicating its role in early event of disease progression. Further, high incidence of disease relapse was found to be present in early stage patients with strong Nibrin expression. Thus, it could be used as a favorable prognostic factor in developing disease recurrence in patients with early stage disease. Further, among various cancers, the different patterns of the Nibrin expression have observed which indicates that the expression of Nibrin is important in cancer development and progression with cancer cell type specificity, although the mechanism behind it is unclear.

\section{Financial support and sponsorship}

This work was supported by the Gujarat Cancer Society and the Gujarat Cancer and Research Institute.

\section{Conflicts of interest}

There are no conflicts of interest.

\section{Patient consent}

Patient consent was obtained from the patients.

\section{Ethics approval}

Ethics approval was obtained from the Gujarat Cancer and Research Institute.

\section{REFERENCES}

1. Bettendorf O, Piffkò J, Bànkfalvi A. Prognostic and predictive factors in oral squamous cell cancer: important tools for planning individual therapy? Oral Oncol 2004;40:110-9.

2. Nagler RM. Molecular aspects of oral cancer. Anticancer Res 2002;22:2977-80.

3. Zbären P, Lehmann W. Frequency and sites of distant metastases in head and neck squamous cell carcinoma. An analysis of 101 cases at autopsy. Arch Otolaryngol Head Neck Surg 1987;113:762-4.

4. Neville BW, Day TA. Oral cancer and precancerous lesions. CA Cancer J Clin 2002;52:195-215.

5. Feller L, Lemmer J. Oral squamous cell carcinoma: epidemiology, clinical presentation and treatment. J Cancer Ther 2012;3:263-8.

6. Facompre N, Nakagawa H, Herlyn M, Basu D. Stem-like cells and therapy resistance in squamous cell carcinomas. Adv Pharmacol 2012;65:235-65.

7. Cohen EE. Novel therapeutic targets in squamous cell carcinoma of the head and neck. Semin Oncol 2004;31:755-68.

8. Scully C, Field JK, Tanzawa H. Genetic aberrations in oral or head and neck squamous cell carcinoma 3: clinicopathological applications. Oral Oncol 2000;36:404-13.

9. Nagpal JK, Das BR. Oral cancer: reviewing the present understanding of its molecular mechanisms and exploring the future directions for its effective management. Oral Oncol 2003;39:213-21.

10. Nagai MA. Genetic alterations in head and neck squamous cell carcinomas. Braz J Med Biol Res 1999;32:897-904.

11. Vilenchik MM, Knudson AG Jr. Inverse radiation dose-rate effects on somatic and germ-line mutations and DNA damage rates. Proc Natl Acad Sci U S A 2000;97:5381-6.

12. Arnott RD, Bernstein PL. What risk premium is "normal"? Financial Analyst J 2002;58:64-85.

13. Petrini JH. The Mre11 complex and ATM: collaborating to navigate $\mathrm{S}$ phase. Curr Opin Cell Biol 2000;12:293-6.

14. Karran P. DNA double strand break repair in mammalian cells. Curr Opin Genet Dev 2000;10:144-50

15. D'Amours D, Jackson SP. The Mre11 complex: at the crossroads of DNA repair and checkpoint signaling. Nat Rev Mol Cell Biol 2002;3:317-27.

16. Cerosaletti KM, Lange E, Stringham HM, Weemaes CM, Smeets D, Sölder B, Belohradsky BH, Taylor AM, Karnes P, Elliott A, Komatsu K, Gatti RA, Boehnke M, Concannon P. Fine localization of the Nijmegen breakage syndrome gene to $8 \mathrm{q} 21$ : evidence for a common founder haplotype. Am J Hum Genet 1998;63:125-34.

17. Nelms BE, Maser RS, MacKay JF, Lagally MG, Petrini JH. In situ visualization of DNA double-strand break repair in human fibroblasts. Science 1998;280:590-2.

18. Pandita TK, Pathak S, Geard CR. Chromosome end associations, telomeres and telomerase activity in ataxia telangiectasia cells. Cytogenet Cell Genet 1995; 71:86-93

19. Metcalfe JA, Parkhill J, Campbell L, Stacey M, Biggs P, Byrd PJ, Taylor AM. Accelerated telomere shortening in ataxia telangiectasia. Nat Genet 1996;13:350-3.

20. Lim DS, Kim ST, Xu B, Maser RS, Lin J, Petrini JH, Kastan MB ATM phosphorylates p95/nbs1 in an S-phase checkpoint pathway. Nature 2000;404:613-7

21. Zhao S, Weng YC, Yuan SS, Lin YT, Hsu HC, Lin SC, Gerbino E, Song MH, Zdzienicka MZ, Gatti RA, Shay JW, Ziv Y, Shiloh Y, Lee EY. Functional link between ataxia-telangiectasia and Nijmegen breakage syndrome gene products. Nature 2000;405:474-7.

22. Wu X, Ranganathan V, Weisman DS, Heine WF, Ciccone DN, O' Neill TB, Crick KE, Pierce KA, Lane WS, Rathbun G, Livingston DM, Weaver DT. ATM phosphorylation of Nijmegen breakage syndrome protein is required in a DNA damage response. Nature 2000;405:477-82.

23. Stumm M, von Ruskowsky A, Siebert R, Harder S, Varon R, Wieacker P, Schlegelberger B. No evidence for deletions of the NBS1 gene in lymphomas. Cancer Genet Cytogenet 2001;26:60-2.

24. Varon R, Reis A, Henze G, von Einsiedel HG, Sperling K, Seeger $\mathrm{K}$. Mutations in the Nijmegen Breakage syndrome gene (NBS1) in childhood acute lymphoblastic leukemia (ALL). Cancer Res 2001;61:3570-2.

25. Plisiecka-Halasa J, Dansonka-Mieszkowska A, Rembiszewska A Bidziński M, Steffen J, Kupryjańczyk J. Nijmegen breakage syndrome gene (NBS1) alterations and its protein (nibrin) expression in human ovarian tumors. Ann Hum Genet 2002;66:353-9.

26. Wilda $\mathrm{M}$, Demuth I, Concannon $\mathrm{P}$, Sperling K, Hameister $\mathrm{H}$. Expression pattern of the Nijmegen breakage syndrome gene, Nbs1, during murine development. Hum Mol Genet 2000;9:1739-44.

27. Featherstone C, Jackson SP. DNA repair: The Nijmegen breakage syndrome protein. Curr Biol 1998;8:622-5. 
28. Digweed M, Reis A, Sperling K. Nijmegen breakage syndrome: consequences of defective DNA double strand break repair. Bioessays 1999;21:649-56.

29. Stracker TH, Petrini JH. The MRE11 complex: starting from the ends. Nat Rev Mol Cell Biol 2011;12:90-103.

30. Hsu DS, Chang SY, Liu CJ, Tzeng CH, Wu KJ, Kao JY, Yang $\mathrm{MH}$. Identification of increased NBS1 expression as a prognostic marker of squamous cell carcinoma of the oral cavity. Cancer Sci 2010;101:1029-37.

31. Ali-Fehmi R, Chatterjee M, Ionan A, Levin NK, Arabi H, Bandyopadhyay S, Shah JP, Bryant CS, Hewitt SM, O’ Rand MG,
Alekseev OM, Morris R, Munkarah A, Abrams J, Tainsky MA. Analysis of the expression of human tumor antigens in ovarian cancer tissues. Cancer biomark 2010;6:33-48.

32. Hall J, Angèle S. Radiation, DNA damage and cancer. Mol Med Today 1999;5:157-64.

33. Ehlers JP, Harbour JW. NBS1 expression as a prognostic marker in uveal melanoma. Clin Cancer Res 2005;11:1849-53.

34. Angèle $S$, Treilleux I, Brémond A, Tanière $P$, Hall J. Altered expression of DNA double-strand break detection and repair proteins in breast carcinomas. Histopathology 2003;43:347-53. 